УДК [378.015.3:005.32]:78.071.2

DOI:

Ірина Савлук, кониертмейстер кафедри теорії і методики музичної освіти та хореографії

Мелітопольського державного педагогічного університету імені Богдана Хмельницького

\title{
ПОЗИТИВНА МОТИВАЦІЙНА СКЛАДОВА ЯК ПРОВІДНА ПСИХОЛОГО- ПЕДАГОГІЧНА УМОВА ВДОСКОНАЛЕННЯ МУЗИЧНО-ВИКОНАВСЬКОЇ МАЙСТЕРНОСТІ СТУДЕНТІВ ЗАКЛАДІВ ВИЩОЇ ОСВІТИ
}

У статті висвітлюється зміст психолого-педагогічних умов (когнітивних, асертивних, аналітичнорефлексивних, інтеграчійних, креативних), необхідних для формування у студентів вмінь повноцінного сприймання та переконливого художньо-виконавського втілення музичних творів. Виділяються найбільи важливі групи позитивних мотивів, щзо впливають на формування стану психічної готовності до публічного виступу. У змісті мотиваційної складової автор поєднує наступні аспекти музично-виконавської підготовки. цілеспрямоване педагогічне керівництво, самостійну виконавську підготовку студента, співтворчу діяльність викладача та студента у процесі побудови виконавської концепції музичного твору.

Ключові слова: мотиваційна складова; психолого-педагогічна умова; музично-виконавська майстерність; студентство; професійна підготовка.

תim. 7.

Iryna Savluk, Accompanist of the Theory and Methodology of Musical Education and Choreography Department, Melitopol Bohdan Khmelnytskiy State Pedagogical University

\section{POSITIVE MOTIVATIONAL COMPONENT AS THE LEADING PSYCHOLOGICALAND PEDAGOGICAL CONDITION FOR IMPROVING MUSIC PERFORMANCE SKILLS OF STUDENTS OF HIGHER EDUCATION INSTITUTIONS}

The article reveals the content of psychological and pedagogical conditions (cognitive, assertive, analyticalreflexive, integrative, creative) necessary for the students to improve the skills of full perception and convincing artistic and performing music. The most important groups of positive motives that influence the formation of the state of mental readiness for public speaking are distinguished, namely: motives connected with the attitude of the musician to the works performed and the corresponding self-actualization; motives related to the artist's attitude to the public; motives related to the attitude to performing activities (motives for professional self-improvement, motives for professional self-expression, self-realization, etc.).

The purpose of the article is to actualize the problem of improving the performance of students in higher education institutions. The task is the theoretical substantiation and representation of the positive motivational component chosen for the study of the model.

The author focuses on the fact that understanding the content of motivation-the main indicator of professional skills of the teacher. Knowledge about why people do what they do is a precondition for helping them realize their own motives and prevent cases when negative or unformed motivation causes some complications.

In the content of the motivational component, the author combines the following aspects of musical-performing training: purposeful pedagogical leadership, which includes the process of learning and the process of education; independent executive training of the student, which combines the reproduction of the teacher's instructions, the search for his own individual interpretation and the development of musical horizons; co-creation activity of the teacher and student in the process of constructing the performance concept of a musical work, which is connected with the creation of a verbal interpretation of the musical image and is aimed at creating a convincing individual and creative interpretation.

Keywords: a motivational component; psychological and pedagogical condition; musical-performing skill; the students' professional training.

П

остановка проблеми та аналіз основних досліджень та публікацій.

Удосконалення змісту професійного становлення студентів в період навчання у вищому педагогічному навчальному закладі є актуальною проблемою сьогодення, оскільки від його якості залежить подальший духовно-інтелектуальний розвиток майбутніх поколінь. Необхідність теоретичної і практичної розробки даного питання обумовлена всезростаючою потребою у гармонійному розвитку особистості майбутнього педагога-музиканта та підвищення рівня його професійної майстерності.

Проблема професійного становлення особистості на етапі навчання у закладі вищої освіти висвітлена у працях В. Аридіна, 
ПОЗИТИВНАМОТИВАЦЙНАСКЛАДОВАЯКПРОВДНАПСИХОЛОГО-ПЕДАГОГІЧНАУМОВА ВДОСКОНАЛЕННЯ МУЗИЧНО-ВИКОНАВСЬКОӤ МАЙСТЕРНОСТІСТУДЕНТІВЗАКЛАДІВ ВИЩОЇОСВІТИ

О. Бондаренка, В. Бутенка, Л. Кандибовича, В. Козакова, Р. Нємова, В. Поплужнього, Т. Шуртакової; 3 питань вдосконалення музично-виконавської підготовки студентів - у працях мистецтвознавців Б. Асаф'єва, Б. Захави, Л. Мазеля, та педагогівмузикантів I. Аксельруда,А. Алексєєва, Л. Баренбойма, Б. Бермана, Й. Гофмана, Г. Когана, С. Корлякової, Ю. Некрасова, С. Савшинського та інших.

Мета статті полягає в актуалізації проблеми вдосконалення виконавської майстерності студентів закладів вищої освіти. Завдання - в теоретичному обгрунтуванні та представленні позитивної мотиваційної складової обраної для дослідження моделі.

Виклад основного матеріалу. У визначені змісту наукового поняття “студент" або “студентство” відіграли важливу роль наукові дослідження таких вчених: Г. Атанова, В. Бутенка, М. Д'яченка та інших.

В науковій літературі поняття “студентство” розглядається як:

- мобільна соціальна група, метою якої $є$ організована за програмою підготовка до виконання високих професійних та соціальних ролей в матеріальному та духовному виробництві, предмет якого $\epsilon$ не річ, а сама людина, особа. Тому головною формою духовного становлення $\epsilon$ навчально-освітня діяльність (Б. Рубінова, Ю. Колесникова) [2];

- група людей молодого віку, об'єднана виконанням потенційно значущих для суспільства спеціальних підготовчих функцій, тимчасово приймаючих участь у суспільно виробничій праці (А. Семашко) [3];

- особлива суспільна група суспільства, резерв інтелігенції - об'єднує в своїх рядах молодих людей віком з 18 до 30 років (Т. Іщенко) [3];

У своєму дослідженні ми спираємося на поняття студентство, яке об'єднує в собі всі зазначені вище визначення. Ми вважаємо, що студентство - ие мобільна соиіальна група молоді, шчо проходить стадію персоналізаціі на основі иілеспрямованого засвоєння навчальних, професійних та соиіальних функиій, діяльність якої направлена на здобуття спеціальних знань, вмінь, навичок необхідних для їх реалізації в обраній професії.

Однією з особливостей студентської молоді $\epsilon$ іiї свідома орієнтація на здобуття вищої освіти та високої професійної підготовки. В сукупності якостей, притаманних для студентства, великого значення набувають його моральні якості, високе почуття обов'язку, розумна міра потреб, та також суспільних та особистісних якостей, рівень цілеспрямованості виконавської діяльності, почуття задоволення при виконанні роботи.

Сучасна психологічна наука розглядає людину не як пасивний об'єкт впливу навколишньої дійсності, а активну діючу істоту, розкриваючи при цьому залежність розвитку індивідуальності особистості від соціальних умов. Зовнішні умови впливають на психічний розвиток людини не безпосередньо, а переломлюючись через їі особистість, індивідуальні психічні особливості, діяльність й життєвий досвід [1, 23].

Психологами виявлено, що студентству притаманне емоційне підвищення, висока самооцінка i, разом $з$ тим, конформізм та часто буденне відношення до звичайного, здатність за одним фактом робити загальні висновки. Студенти вже можуть контролювати свої емоції, аналізувати їх прояви. Мають можливість мотивувати виникнення тієї чи іншої емоції під час слухання чи виконання музичного твору. В психології студентський вік називають перехідним становищем від юнацького віку до дорослості.

Ефективність формування виконавської майстерності студентів обумовлена створенням у навчальному процесі цілої низки психологопедагогічних умов, які забезпечують успішність даного процесу.

При висвітлення змісту поняття "умова" ми зіткнулись із твердженням, що умови це постійні фактори, котрі сприяють створенню відношень предмета до навколишнього середовища та явищ, без яких він не може виникнути та існувати. При цьому кінцевий результат впливу визначається, як правило не окремо взятими причинами, а їх сукупністю. А також має тісний зв'язок з усіма зовнішніми та внутрішніми умовами, які в свою чергу виступають підсумком, попередніх взаємодій.

У музично-педагогічній діяльності поняття “умова” застосовується у значенні спеціально створеного та тематично спрямованого емоційнопізнавального середовища, необхідного для засвоєння студентами емоційно-образного змісту музичних творів, посилення відчуття їх впливу на емоційний стан особистості та підвищення майстерності втілення власної виконавської концепції $[7,86]$.

До складу психолого-педагогічних умов, необхідних для формування вмінь повноцінного сприймання та переконливого художньовиконавського втілення музичних творів науковці відносять:

а) когнітивні - що забезпечують інформаційне забезпечення процесу формування музичновиконавської майстерності; 
ПОЗИТИВНАМОТИВАЦЙНАСКЛАДОВАЯКПРОВІДНАПСИХОЛОГО-ПЕДАГОГЧНАУМОВА ВДОСКОНАЛЕННЯ МУЗИЧНО-ВИКОНАВСЬКОӤ МАЙСТЕРНОСТІСТУДЕНТІВЗАКЛАДІВ ВИЩОӤОСВІТИ

б) асертивні, що передбачають формування відповідної психологічної установки та розвиток незалежності власної виконавської концепції від зовнішніх впливів;

в) аналітично-рефлексивні, які відображають рівень розвитку вмінь аналізу, емоційноестетичного переживання та емпатійного проникнення до художнього змісту музичних творів;

г) інтеграційні (або асоціативні), метою яких виступає забезпечення взаємодії мистецтв у процесі розвитку загальної культури музиканта виконавця;

д) креативні, що відтворюють інноваційну складову музично-виконавського процесу i спонукають майбутнього фахівця до творчих пошуків у музично-виконавській діяльності.

Однією $з$ провідих психолого-педагогічних умов вдосконалення музично-виконавської майстерності студентів закладів вищої освіти $€$ позитивна мотивація.

Мотивація у психологічному значенні - це процес зовнішнього та внутрішнього стимулювання суб'єкта до здійснення ефективної діяльності, спрямованої на досягнення мети. Наявність стійкої мотивації необхідна для ефективного виконання прийнятих рішень i запланованих завдань. Мотивація - це необхідна складова успішного результату, оскільки є внутрішньоособистісним утворенням та сприяє досягненню задоволення від залучення до певної діяльності та, як наслідок, якісному її виконанню.

У науковій літературі існують два основні підходи до вивчення теорій мотивації:

1. Один підхід грунтується на дослідженні змістовної сторони теорії мотивації, тобто теорії базуються на вивченні потреб людини, якіі є основними мотивом їх проведення, а отже, ідіяльності(А. Маслоу, Ф. Герцберга і Д. Мак-Клелланда).

2. Другий підхід базується на процесуальних теоріях, де увага спрямовується на раціональному розподілі зусиль студентів та виборі певного типу поведінки для досягнення конкретних цілей (до них відносяться теорія очікувань або модель мотивації по В. Вруму, теорія справедливості або модель Портера - Лоулера).

Психологи надають особливого значення особистісним факторам, які детермінують навчання: мотивації, інтересам, потребам, прагненням, домаганням. Адже всі психічні процеси людини (сприйняття, увага, установка, пам'ять, мислення тощо) спонукаються мотивацією людини, іiї спрямованістю на цілі, результати професійної діяльності.

Обгрунтовуючи змістовні критерії та вияви музично-педагогічного професіоналізму, Г.П. Панченко вказує на наявність у його структурі мотиваційно-ціннісного компоненту, у змісті якого присутні такі складові: “... потреба у певній діяльності, визначення і усвідомлення іiі мети, систематизація існуючого досвіду і пошук необхідних засобів вирішення проблемних завдань тощо" $[5,136]$, що характеризують професійні можливості майбутнього фахівця.

Розуміння змісту мотивації - головний показник професійної майстерності викладача. Знання про те, чому люди роблять те, що вони роблять - необхідна передумова для того, щоб допомогти їм реалізувати власні мотиви та попередити випадки, коли негативна або несформована мотивація може викликати певні ускладнення. Наприклад, на початковому етапі навчання мотивація виконавця при підготовці до концерту може бути пов'язана не тільки 3 уявленням про виконавську діяльність як засіб освоєння цінностей культури і передачі їх слухачам, 3 уявленням про учіння як шляху до здійснення свого призначення в житті, але і 3 особистісними мотивами - прагненням до зовнішніх атрибутів вчення (оцінок, атестату), часто при відсутності необхідного інтересу до процесу навчання. Численні дослідження російських психологів свідчать про те, що вузько особистісна мотивація при всій різноманітності їі типів не володіє, за рідкісним винятком, такою спонукальною силою, як широка соціальна мотивація, мобілізуюча цінні сторони особистості. Тому завдання педагога полягає у вихованні соціально-цінних домагань, мотивів, пов'язаних 3 самим процесом навчання, а також у виправленні “негативної мотивації” [4, 217].

Дуже важливим є формування позитивної мотивації музиканта, оскільки саме мотиваційнопотребова сфера виступає могутнім психологічним механізмом діяльності. Незважаючи на різноманіття форм публічних виступів існують деякі загальні аспекти мотивації підготовки до концертного виступу. Серед них ми виділили найбільш важливі групи позитивних мотивів, що впливають на формування стану психічної готовності до концерту:

1) мотиви, пов'язані зі ставленням музиканта до виконуваних творів та відповідною самоактуалізацією;

2) мотиви, пов'язані зі ставленням виконавця до публіки;

3) мотиви, пов'язані зі ставленням до виконавської діяльності (мотиви професійного самовдосконалення, мотиви професійного самовираження, самореалізації тощо). 


\section{ПОЗИТИВНАМОТИВАЦЙНАСКЛАДОВАЯКПРОВІДНАПСИХОЛОГО-ПЕДАГОГІЧНАУМОВА ВДОСКОНАЛЕННЯМУЗИЧНО-ВИКОНАВСЬКОЇ МАЙСТЕРНОСТІСТУДЕНТІВЗАКЛАДІВ ВИЩОЇОСВІТИ}

В. Ражніков, взявши за основу поділ мотивації на внутрішню і зовнішню (за М. Ярошевським), показав на основі бесід з визначними російськими диригентами, що провідним внутрішнім мотивом як умовою формування ідеальної концепції при підготовияі до виступу $\epsilon$ можливість знайти в творі те, щцо найбільще відповідає виконавській індивідуальності, смаку музиканта. Важливе значення мають i зовнішні мотиви: бажання самоствердитися через твір, який близький за духом і настроєм, підтвердити свою компетентність інтерпретатора. Автор відзначає, що внутрішні і зовнішні мотиви у поєднанні виступають як стимули творчого процесу [6, 220].

Мотиваційна складова $є$ основоположною у комплексі психолого-педагогічних умов та передбачає усвідомлення студентом необхідності та значущості досконалого володіння музичним інструментом. У змісті вказаної складової поєднано наступні аспекти музично-виконавської підготовки:

1. Цілеспрямоване педагогічне керівництво, яке включає:

a) процес навчання - спеціально організовану, керовану та контрольовану взаємодію учителя з учнем, спрямовану на засвоєння ним знань, вмінь та навичок, формування світогляду, розвиток розумових сил і потенційних можливостей, закріплення навичок самоосвіти відповідно до поставлених завдань;

б) процес виховання - систему виховних заходів, спрямованих на збагачення музичнослухового та музично-виконавського досвіду студента, вдосконалення музично-естетичних ідеалів та смаків, формування аксіологічних пріоритетів особистості у музичному мистецтві.

2. Самостійна інструментально-виконавська підготовка студента:

a) самостійна робота, що базується на відтворенні вказівок викладача, зазначених під час уроку - тобто репродуктивно-технологічне виконання завдань;

б) самостійна діяльність спрямована на пошук індивідуально-творчої інтерпретації; на цьому етапі студент слухає та порівнює твори своєї програми у виконанні різних майстрів різних часів, відбувається осмислення, оцінювання та експлікація на власну інтерпретацію;

в) самостійна індивідуальна робота 3 метою розвитку музичного кругозору, світогляду, задля збагачення особистості студента, поштовху до розуміння краси, виховання художнього смаку, а також гармонійного характеру; це досягається шляхом читання ретельно підібраної класичної літератури, музичної спадщини педагогівмузикантів, відвідування театрів, філармоній, виставочних залів, спілкуванням 3 провідними викладачами та митцями сьогодення.

3. Співтворча діяльність викладача та студента у процесі побудови виконавської концепції музичного твору:

a) співтворча діяльність пов'язана із створенням словесної інтерпретації музичного образу є ефективною для розвитку образного мислення, для здатності в усній формі на основі отриманих знань яскраво і переконливо викладати свої думки. Для застосування методу словесної інтерпретації музичного образу на заняттях 3 основного музичного інструмента доцільно застосовувати наступні завдання:

- на основі аналізу музичних творів та суджень професійних музикознавців скласти усну анотацію до музичного твору на аналогічному розкритті в ній образного змісту музики;

- поєднати виконання музичного твору з його мовним поясненням почергово студентом та викладачем з обговоренням позиції кожного;

- обгрунтувати своє трактування твору із залученням теоретико-історичних та методичних джерел;

б) співтворча діяльність спрямована на створення переконливої індивідуально-творчої інтерпретації; на цьому етапі доцільно застосовувати:

- системний аналіз студентом та викладачем різних виконавських концепцій, редакцій, музичнопубліцистичних джерел з критичним оглядом або описом виконання даного твору;

- побудову “виконавського сценарію” дій для адекватного інструментального втілення виконавської концепції. Слід зазначити, що поняття “виконавський сценарій” передбачає більшу свободу дій та гнучкість ситуативного реагування у виконанні у порівняні з виконавським планом, оскільки при написанні “виконавського сценарію” продумуються та передбачаються декілька варіантів виконавської концепції із урахуванням багаточисленних зовнішніх і внутрішніх факторів (емоційний та фізичний стан виконавця, місце твору в концертній програмі, підготовленість аудиторії тощо).

Траєкторія подальших досліджень у руслі даної проблематики спрямована на розробку методики формування позитивної мотиваційної складової як провідної психолого-педагогічноӥ умови вдосконалення музично-виконавської майстерності студентів та її експериментальну перевірку в реаліях навчального процесу вищих закладів освіти. 


\section{ЛІТЕРАТУРА}

1. Максименко С.Д. Загальна психологія. Вінниця, 2004. 704 с.

2. Мойсеюк Н.Є. Педагогіка: навчальний посібник. 5-те видання, доповнене і перероблене. Київ, 2007. 656 с.

3. Некрасов Ю.М., Грінберг М. Єдність педагогічних та виконавських принципів навчання у роботі. Теоретичні та практичні питання культурології. Випуск Х. Мелітополь, 2002. С. 81-92.

4. Немов Р.С. Психология: учеб. для студ. высш. пед. учеб. заведений: в 3 кн. Москва, 2001. 4-е изд. кн. 1: Общие основы психологии. 2001. С. 158-390.

5. Панченко Г.П. Змістовні критерії та вияви музично-педагогічного професіоналізму як компетентнісні маркери організації вокальної підготовки майбутнього вчителя музичного мистецтва. Музично-педагогічний професіоналізм вчителя мистецтва: історія, методологія, освітня практика: монографія /Авт. кол.; за заг. ред. Н.А.Сегеда. Мелітополь, 2016. С. 131-161.

6. Психология музыкальной деятельности: Теория и практика: учебное пособие для студ. муз. фак. высш. пед. учеб. заведений/ Д.К.Кирнарская, К.В.Тарасова и др.; под ред. Г.М.Цыпина. Москва, 2003. $368 \mathrm{c}$.

7. Рудницька О.П. Педагогіка: загальна та мистецька: навчальний посібник. Тернопіль, 2005. $360 \mathrm{c}$.

\section{REFERENCES}

1. Maksymenko, S. (2004). Zahalna psykholohiia [General psychology]. Vinnitsa, 704 p. [in Ukrainian].

2. Moiseiuk, N. (2007). Pedahohika: navchalnyi posibnyk [Pedagogy: tutorial]. Kyiv, 656 p. [in Ukrainian].
3. Nekrasov, Y. (2002). Yednist pedahohichnykh ta vykonavskykh pryntsypiv navchannia u roboti M. Hrinberh: teoretychni ta praktychni pytannia kulturolohii [Unity of pedagogical and executive principles of teaching in the work of M. Greenberg : theoretical and practical questions of cultural studies]. Melitopol, pp. 81-92. [in Ukrainian].

4. Nemov, R. (2001). Psikhologiya: ucheb. dlya stud. vyssh. ped. ucheb. zavedeniy [Psychology: study for the students of higher pedagogical institutions]. Moscov, pp. 158-390. [in Russian].

5. Panchenko, H. (2016). Zmistovni kryterii ta vyiavy muzychno-pedahohichnoho profesionalizmu yak kompetentnisni markery orhanizatsii vokalnoi pidhotovky maibutnoho vchytelia muzychnoho mystetstva : Muzychno-pedahohichnyi profesionalizm vchytelia mystetstva: istoriia, metodolohiia, osvitnia praktyka: monohrafiia [Substantive criteria and demonstrations of musical and pedagogical professionalism as competency markers of organization of vocal training of the future teacher of musical art : Music-pedagogical professionalism of the teacher of art: history, methodology, educational practice: monograph]. Melitopol, pp. 131-161. [in Ukrainian].

6. Kirnarskaya, D. \& Tarasova, K. (2003). Psikhologiya muzykalnoy deyatelnosti: Teoriya $i$ praktika: Uchebnoe posobie dlya stud. muz. fak. vyssh. ped. ucheb. [Psychology of musical activity: theory and practice: tutorial for the student. of mus. fac. of higher pedagogical institutions]. Moscow, $368 \mathrm{p}$. [in Russian].

7. Rudnytska, O. (2005). Pedahohika: zahalna ta mystetska: navchalnyi posibnyk [Pedagogy: general and artistic: Textbook]. Ternopil, 360 p. [in Ukrainian].

Стаття надійшла до редакції 20.06.2019

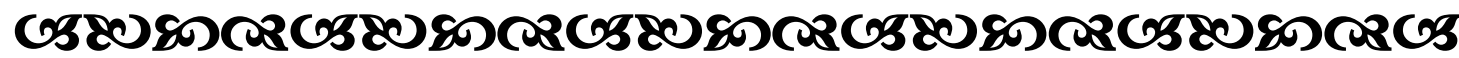

“Здатність зақладена заздалегідь, але вона повинна стати умінням”.

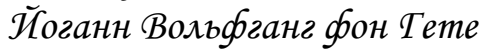
німещький поет, прозаїк

“Усе своє життя старанно навчайся. Кожен день ставай майстернішим, ніж ти був за день до чього, а на наступний день-майстернішим, ніж сьогодні. Вдосқоналення не має кіния".

Ямиамото भूунетомо білософ, письменник

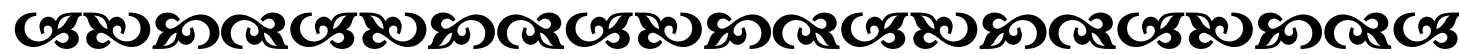

